\title{
Commercial Banks Loans and Lending Rate in Nigeria: A Toda-Yamamoto Causality Approach
}

\author{
Andrew.A. Igwemma ${ }^{1} \quad$ Callistus Ogu $^{1} \quad$ Agba Ugochuckwu Pascal $^{1}$ \\ Joseph Chukwudi Odionye ${ }^{2}$ Ogu Lucy Chika ${ }^{3}$ \\ 1.Department of Economics, Imo State University Owerri, Imo State, Nigeria \\ 2.Department of Economics Abia State University Uturu Nigeria \\ 3.Department of Economics Madonna University Okija Nigeria
}

\begin{abstract}
This study examined the relationship between commercial banks loans and lending rate in Nigeria for the period of 1981 to 2016. The study employed the augmented Granger causality test approach developed by Toda and Yamamoto (1995). This study is motivated by the fact that commercial banks loans and lending rate is the key to development and growth of every economy through the manufacturing sector, Agricultural sector, and industrial sector. The specific objectives of the study are; to examine the causality between commercial banks loans and lending rate, to examine the causality between commercial banks loans and money supply, and to examine the causality between commercial banks loans and monetary policy rate. The objectives shall be examined using an alternative causality testing approach of Toda-Yamamoto (1995). The proposed data employed shall be from Central Bank of Nigeria statistical bulletin (2016). The results are expected to illustrate the extent to which commercial banks loans and lending rates has affected the investment sector of the economy and suggest ways of cushioning the negative effects
\end{abstract}

Keywords: Commercial bank loans, Lending rate, Toda and Yamamoto causality.

DOI: $10.7176 / \mathrm{JESD} / 11-2-02$

Publication date: January $31^{\text {st }} 2020$

\section{Introduction}

Bank Lending is a very important function of the banking system, providing liquidity in the economy, profitability of the banks through the interest charged as well as impacting on the economic growth rate and the business net worth of nations. Okpara (2009) explains that the banking sector helps to make credits available by mobilizing surplus funds from savers who have no immediate needs for such funds and thus, channel such funds in form of credits to the investors who have brilliant ideas on how to create additional wealth in the economy but lack the necessary capital to execute such ideas. Banks are generally in the business for profit making.

Banks across the country are following increasingly differentiated pricing strategies aimed at maximizing profits since this is the ultimate goal of any business organization. These strategies are more or less dependent on the Central Bank of Nigeria's Monetary Policy Committee (MPC) directives regarding inflationary trends and prime rates (CBN, 2016). In their bid to attract customers, increase market shares and to stay competitive as well as operate within the ambiance of laws governing banking, $\mathrm{CBN}$ then come out with attractive products and services such as giving of loans that intend to attract the customers (borrowers) and charge certain fees and commissions. Lending rates are the charges made to borrowers when they take loans from the bank. The Lending rate has different effects to customers (borrowers) and the banks. Bank customers, investors, government and all those affected by lending rates and the banks themselves have in recent times reacted variedly to changes in prime rate and base rate, fees and commissions. While some argue that Lending rates are high and scare away borrowers and other investors, banks also argue that operational cost and cost of providing efficient services are exorbitant and need to recover these costs in order to stay in business.

Theoretically, there exist the relationships between commercial banks loan and lending rate or interest rate charged but empirically no consensus on the direction of causality between lending rate and commercial bank loans. Economic theory offers two seemingly contradictory views of this relationship. One view, which follows from the interaction of loanable money demand and supply, is that money and interest rates are negatively related: increasing interest rates, for example, requires a decrease in the stock of loanable money. According to this view, money demand is a decreasing function of the nominal interest rate because the interest rate is the opportunity cost of holding cash (liquidity). So a decrease in the supply of loanable money must cause interest rates to increase in order to keep the money market in equilibrium. (Hammed, 2011; Gichuki, Oduor and Kosimbei, 2012). Lending rate serves as both cost of borrowing to the investors who have business ideas but lack necessary capital to execute such ideas and returns on savings to surplus financier who have no immediate need for the money. On one hand, as a cost of borrowing to the investor, high cost of borrowing will deter investors from getting loan from the banks and vice versa. This suggests a one way direction of causality from lending rate to commercial banks loans. On the other hand, increased in demand for commercial banks loans can influence the lending rate in a market determined interest rate. In such case, the direction of causality runs from loans to lending rate. 
Although, many researchers have studied on banking sectors lending rate in Nigeria, to the best of our knowledge no research work has been done on the causal relationship between commercial bank loans and interest rate variation in Nigeria. This study sought to examine the causality of bank loans and interest rate charged using an alternative causality testing approach of Toda-Yamamoto (1995). This work is structured as follows: following the introductory part is section two which explains the theoretical and conceptual issues, section three is the methodological issues, section four is discussion of the analyses and section five is conclusion and policy recommendations.

\subsection{Literature Review}

Interest rate spread is one of the measures of financial sector efficiency. According to Sepehri and Moshiri (2004), interest rate is the rate of return on investment and the cost of borrowing funds. The interest rate is determined by the demand and supply of money. Among the many industries affected by fluctuations in interest rates, real estate and banking are perhaps the most directly impacted. When interest rates increase, borrowing becomes more expensive, dampening consumer demand for mortgages and other loan products and negatively affecting residential real estate prices. Rising interest rates can also lead to increased default rates, as holders of adjustable rate debt find themselves faced with higher payments. Vendors of mortgage backed securities, which consist of bundled mortgages, will see their ability to monetize the securities lessens as a result of the deterioration of the quality of the underlying asset (Buiter, 2009).

Interest-rate targets are a vital tool of monetary policy and are taken into account when dealing with variables like investment, inflation, and unemployment. The central banks of countries generally tend to reduce interest rates when they wish to increase investment and consumption in the country's economy. However, a low interest rate as a macro-economic policy can be risky and may lead to the creation of an economic bubble, in which large amounts of investments are poured into the real-estate market and stock market (Benchimol, 2013). This happened in Japan in the late 1980s and early 1990s, resulting in the large unpaid debts to the Japanese banks and the bankruptcy of these banks and causing stagflation in the Japanese economy (Japan being the world's second largest economy at the time), with exports becoming the last pillar for the growth of the Japanese economy throughout the rest of 1990s and early 2000s.

The traditional analysis of the commercial banking sector posits that the assets of the banks should mainly be of a short-term maturity, as this would allow banks to effectively meet their demand deposit liabilities when required (Roussakis, 1977). Larger loans with greater maturity periods would be charged a higher rate of interest than smaller loans with lower maturity periods. However, in response to changing private sector credit demand, increased technology in the banking industry and new banking techniques, commercial banks' portfolios have shifted towards consenter, mortgage and business loans, with an increase in maturity periods (Codrington and Coppin, 1987). Thus, modern commercial banks are much less constrained to holding short-term liquid assets. As a result of this shift in commercial banking policy, it has been argued that commercial banks are biased against certain types of borrowers. For example, because of the relatively greater risk of small businesses, they are usually charged higher rates of interest in comparison to larger business (Strahan, 1999). This is closely related to the credit rationing literature based on the contributions of Keeton (1979) and Stiglitz and Weiss (1981). These models assume that the same loan contract is offered to loan applicants exhibiting differing risks of insolvency. It is then shown that equilibrium credit rationing can occur in credit markets with imperfect information if the positive effect of an increase in the interest rate on bank's profit, is outweighed by the negative adverse selection effect induced by a declining average probability of loan repayment.

The cost of lending which is proxied by bank lending interest rates influences the demand for loanable fund. Although, there is consensus on the use of bank lending rates as an argument in the demand for loan model, some studies argue that the cost of lending should be adjusted to reflect the opportunity cost of bank loans. For instance, Friedman and Kuttner, (1993) asserted that the demand for loans is influenced by not only on the own price of the borrowed funds, but also the price of funds obtained from other internal or external sources. There is however a no consensus on the relationship between the cost of loan (interest rate) and demand for credit. Whiles some argue that the relationship is negative, (Weiss, 1981: Stiglitz, 1989: and Besley, 1994) others consider it to be neutral. Those who argue for the adverse relationship between demand for credit and the interest rate advocate that high interest adversely affect demand for credit because only limited borrowers with high risk projects may have their demand satisfied. Prominent among those who hold this view are Stiglitz and Weiss (1981), Stiglitz (1989) and Besley (1994). Their argument is based on the fact that high interest rates encourage adverse selection of loan seekers. Those who take high risk and get their loans approved are those with high default rates. Nehman (1973) in his work on the analysis of demand for rural credit among farmers in Sao Paolo, Brazil, observed that borrowing costs strongly affect the willingness of the rural poor to seek loans from the formal sector. Although the work by Aryeetey et. al. (1994), on the supply and demand of finance of small enterprises in Ghana, did not make any explicit nexus between interest rate and demand for loans, it did show implicitly that demand for credit at $30 \%$ lending rate was somewhat weaker. 


\subsection{EMPIRICAL REVIEW}

Ajayi and Atanda (2012) investigated the impact of monetary policy instruments on banks performance between 1980 and 2008. The study used Engle-granger two-step co-integration approach for it analysis. The result indicated that bank rate, inflation rate and exchange rate are credit enhancing variables, while liquidity ratio and cash reserves ratio exert negative impact on banks total credit. Although, it is only cash reserve ratio and exchange rate found to be significant at $5 \%$ critical value. The study found that monetary policy instruments are not significant to stimulate credit in the long-run, while banks total credit is more responsive to cash reserve ratio.

Agbonkhese and Asekome (2013) examined the effects of monetary policy on the deposit money banks' credit creation in Nigeria. The study covered the period between 1980 and 2010 and used Ordinary Least Square (OLS) method of data analysis. Their empirical results revealed that there was a positive and direct relationship between the total deposits and treasury bills rate. Whereas, the reserve requirement and interest rate had negative effects on the total credit creation. Therefore, the reserve requirements is not an effective monetary policy instrument to influence bank credit to achieve a desired monetary policy objective since money deposit banks could on their own easily raise and keep substantial deposits as reserve.

Andreas (2001) investigated the reaction of bank lending to monetary policy measures in Germany. Empirical evidence from dynamic panel estimations based on a data set that comprises individual balance sheet information on all German banks. It shows that the average bank reduces its lending more sharply in reaction to a restrictive monetary policy measure the lower its ratio of short-term interbank deposits to total assets. A dependence on its size can only be found if explicitly controlled for this dominating effect and/or if the very small banks are excluded.

Tsenkwo and Longdu'ut (2013) examined the Relationship between Monetary Policy Rate (MPR) and Banking Rates: Evidence from Regression and Multivariate Causality Analysis. The study used descriptive statistics and econometrics analysis to subject the raw data from secondary source to series of refining like Unit Root Test, Ordinary Least Square Test, Stability Test, and Granger causality test. These tests were conducted, using Granger causality test, to know the direction of their relationships and how they are caused. The finding revealed that almost all the variables, with the exception of bank savings rate, exhibit a strong sign of co-moving in the long run with the tendency of converging. The research revealed that there exist unidirectional causality between monetary policy rate and bank lending rate; bank lending rate and bank savings rate. And there exist a bidirectional causality between monetary policy rate and bank savings rate.

Ayub and Seyed (2016) in their study the relationship existing between monetary policy and bank lending behavior and the influence of bank specific features on this relationship in the banks listed on the 8 Tehran Stock Exchange. The study used Iran's bank loan aggregated series and bank's size and capital structure data. The study used the growth rate of M2 as the indicators of Irans' monetary policy. Using Vector error correction model (VECM) and quarterly data for the period 2007:Q1 to 2014:Q4. The results showed a bidirectional causal link between M2 and banks lending behavior trading on the Tehran Stock Exchange. It was also observed that the banks' capital structure as one of the banks specific feature variables have a negative impact on bank lending behavior in accepted banks in Tehran Stock Exchange.

Otalu, Aladesanmi and Mary (2014) assessed the impact of monetary policy on the deposit money banks performance in Nigeria, and in their study, the interest rate and money supply, liquidity ratio and the cash reserve ratio were used as proxy for monetary policy. The study used regression analysis to examine the relationship between monetary policy and bank performance in Nigeria. The results of the diagonistic test showed that credit creation of commercial banks is significantly being influenced by the interest rate, money supply, liquidity ratio and the cash reserve. Precisely, money supply and cash reserve ratio appeared to have statistically influenced deposit money banks' credit creation.

Jegede (2014) empirically researched on the impact of monetary policy on commercial bank lending in Nigeria between 1998 and 2008. Vector Error Correction Mechanism of Ordinary Least Square was used as the tool for analysis. The findings of the study indicated that there exists a long run relationship among the variables in the model. Specifically, the findings also found that exchange rate and interest significantly influenced commercial bank lending, while liquidity ratio and money supply exert negative impact on commercial banks' loan and advance.

Ayieyo (2016) identified the effect of deposit size and interest rate on total loans from nine commercial banks in Kenya over a ten-year period from 2002 to 2011. Using the multiple regression analysis, the results indicated that interest rates were negatively correlated and significantly affected the total loans provided. In addition, the volume of deposits has a significant and direct impact on the total loans provided. The study recommended that commercial banks should set up ways to increase their profits through fee and commission income as interest rate yields go down as lending rates increase.

Akinlo and Oni (2015) utilized the error correction modeling technique to investigate the leading factors influencing bank credit presented to the private sector over the period 1980-2010. The consequences show credit was likely increased by the effect of broad money, cyclical risk premium and liquidity ratio. On the contrary, prime lending rate and reserve ratio cause a reduction in credit. Moreover, private credit rises with inflation, but not one 
to one, sense that inflation tends to reduce real bank credit.

By using Ordinary Least Square (OLS), Malede (2014) conducted a study using financial data for eight Ethiopian commercial banks over a period of seven years from 2005 to 2011. This study showed evidence of the effect of size, credit risk, GDP ratio and liquidity on lending in commercial banks, while it did not show any evidence of the effect of deposits, investment, cash reserve required and interest rates.

Hanh (2014) also used financial data for 146 different countries at the level of economic growth and for twenty-four years in the period 1990-2013 in an attempt to study the determinants of bank credit. This study found that the country's economic growth affects bank credit. The study also found that the strength of the banking system has had an impact on the bank's progress. By contrast, dependence on foreign capital inputs makes its banking sector more vulnerable to external turmoil. In addition, in an attempt to identify the factors that could affect bank lending.

Moreover (Amidu, 2014), through bank statements, of 264 banks spread across 24 sub- Saharan African countries showed that regulation of the banking market affects the provision of credit in an environment in which the financial sector is improved and banks are allowed to operate freely. In contrast, there was a sign of a relationship between bank credit and financial strength of banks.

Ladime, Sarpong-Kumankomah and Osei (2013) conducted a study on the determinants of bank lending behavior in Ghana. Where they found that the behavior of bank lending is directly and positively affected by the size of the bank and the structure of bank capital and also found evidence of the negative impact of the central bank lending rate and exchange rate. And in the Turkish context, Tomak (2013) used quarterly data for fifteen commercial banks and three state banks from 2003 to 2012 to find that the performance of the commercial loans depends on size, total liabilities, and bad loans on total loans, as well as inflation rate.

In the same area of interest, Chernykh and Theodossiou (2011) led research on Russian banks. The study showed that the bank's ability to provide more long term loans is affected by the capital, the size and availability of long term liabilities. It also found that banks are reluctant to grant loans with a repayment period of more than 3 years. In addition, the study stated that banks with a low level of capital provide shorter term loans, and that banks operating in highly competitive regions are reluctant to grant long term loans. The study also indicated that the bank's owners had no impact on loan volume.

In addition and as against general expectations, the study found that return on average assets ratio was a negative impact on the volume of loans but there was a positive effect of return on equity. With regard to the situation in the Jordanian market, Rababah (2015) reviewed the banking lending factors in Jordan during 20052013 by using the ratio of credit facilities to total assets as a response variable. The study showed that the ratio of non-performing loans, liquidity ratio and window rate have a negative impact on credit facilities. However, the study showed that the size of the bank and economic growth have a direct and significant impact on the ratio of loans as well.

In the same field, Alkilani and Kadummi (2015) indicated that the behavior of lending is heavily influenced by internal factors such as net profit after tax and is influenced by external factors such as GDP. The study also pointed out that the volume of loans provided by Jordanian banks is not affected by the interest rate. Finally, the study recommended that the determinants of lending are not all agreed, further analysis is needed to achieve further agreement between studies.

Afolabi , Adeyemi , Salawudeen , and Fagbemi, (2018), examined Monetary Policy and Bank Credit in Nigeria: A Toda-Yamamoto Approach, the result shows that, that there is no long run relationship among the variables used for the study. The result obtained from the Toda and Yamamoto granger non casualty model shows that MPR and CRP is the only variable with bidirectional causal relationship and all other variables tested (M2, LR, INFR and CRR) in this study have no causal relationship with CRP within the period of study. The study revealed that structural changes in monetary policy system incorporated into the study shows statistically significant result affecting CRP in Nigeria.

\subsection{Summary of Literature/Gap}

Although, many researchers have studied on banking sectors lending rate in Nigeria, to the best of our knowledge no research work has been done on the causal relationship between commercial bank loans and interest rate variation in Nigeria. This study sought to examine the causality of bank loans and interest rate charged using an alternative causality testing approach of Toda-Yamamoto (1995).

\subsection{Definition of Model Variables and Methodology}

Annual series data from 1981 to 2016 sourced from Central Bank of Nigeria statistical bulletin (2016) were employed. Commercial bank loans proxied by commercial bank loans and advances (CBL), while commercial bank lending rate (LER), money supply (MOS), and monetary policy rate (MPR) represent the financial institution interaction. To fully explore the data generating process, we first examined the time series properties of model variables using the Augmented Dickey- Fuller test. 
The ADF test regression equations with constant are:

$$
\begin{aligned}
& \triangle C B L_{t}=\alpha_{0}+\alpha_{1} C B L_{t-1}+\sum_{j=1}^{k} a_{j} \Delta C B L_{t-1}+\varepsilon_{t} \cdots \\
& \triangle L E R_{t}=\beta_{0}+\beta_{1} L E R_{t-1}+\sum_{j=1}^{k} \quad b_{j} \Delta L E R_{t-1}+\varepsilon_{t} \cdots \\
& \triangle M O S_{t}=\gamma_{0}+\gamma_{1} M O S_{t-1}+\sum_{j=1}^{k} \varphi_{j} \Delta M O S_{t-1}+\varepsilon_{t} \cdots \\
& \triangle M P R_{t}=\lambda_{0}+\lambda_{1} M P R_{t-1}+\sum_{j=1}^{k} \sigma_{j} \Delta M P R_{t-1}+\varepsilon_{t} \cdots
\end{aligned}
$$

where $\Delta$ is the first difference operator $\varepsilon_{\mathrm{T}}$ is random error term that is iid $\mathrm{k}=$ no of lagged differences In equations (1) through (4), the null hypothesis holds as:

Ho: $\alpha_{\mathrm{i}}=\beta_{\mathrm{i}}=\gamma_{\mathrm{i}}=\lambda_{1}=1$ (unit root) $\mathrm{H}_{1}: \alpha_{\mathrm{i}} \neq \beta_{\mathrm{i}} \neq \gamma_{\mathrm{i}} \neq \lambda_{1}<1$ (level stationary)

where $\mathrm{j}$ is the lag length, $\mathrm{K}$ is the maximum distributed lag length $\alpha_{0}, \beta_{0}, \gamma_{0}, \lambda_{0}$, are the constant terms $\varepsilon_{T}$ is independent and identically distributed error term.

The relationship between commercial bank loans and lending rate can be represented in a dynamic Vector Error Correction Model (VECM) as follows:

$$
\begin{aligned}
& \Delta C B L_{t}=\beta_{0}+\beta_{1} \sum_{i=1}^{q} \Delta C B L_{t-1}+\beta_{2} \sum_{i=1}^{q} \Delta L E R_{t-1}+\beta_{3} \sum_{i=1}^{q} \Delta M O S_{t-1}+\beta_{4} \sum_{i=1}^{q} \Delta M P R_{t-1}+\phi_{1} E C M_{t-1}+\varepsilon_{1 t} \cdots \\
& \Delta L E R_{t}=\beta_{0}+\beta_{1} \sum_{i=1}^{q} \Delta L E R_{t-1}+\beta_{2} \sum_{i=1}^{q} \Delta C B L_{t-1}+\beta_{3} \sum_{i=1}^{q} \Delta M O S_{t-1}+\beta_{4} \sum_{i=1}^{q} \Delta M P R_{t-1}+\phi_{2} E C M_{t-1}+\varepsilon_{1 t} \ldots \\
& \Delta M O S_{t}=\beta_{0}+\beta_{1} \sum_{i=1}^{q} \Delta M O S_{t-1}+\beta_{2} \sum_{i=1}^{q} \Delta C B L_{t-1}+\beta_{3} \sum_{i=1}^{q} \Delta L E R_{t-1}+\beta_{4} \sum_{i=1}^{q} \Delta M P R_{t-1}+\phi_{3} E C M_{t-1}+\varepsilon_{1 t} \cdots \\
& \triangle M P R_{t}=\beta_{0}+\beta_{1} \sum_{i=1}^{q} \Delta M P R_{t-1}+\beta_{2} \sum_{i=1}^{q} \Delta C B L_{t-1}+\beta_{3} \sum_{i=1}^{q} \Delta L E R_{t-1}+\beta_{4} \sum_{i=1}^{q} \Delta M O S_{t-1}+\phi_{4} E C M_{t-1}+\varepsilon_{1 t} \ldots
\end{aligned}
$$

where $\beta^{\mathrm{s}}$ are parameters to be estimated, $\Delta$ is the difference operator, $\varepsilon_{\mathrm{t}}, \mathrm{k}$ are as defined above. The parameter

$\phi_{i}$ where $\mathrm{i}=1,2, \ldots, 4$ should be negative $(<0)$.

Following Sinha and Sinha (2007) and Rambalg and Doran (1996) as cited in Agu and Chukwu (2008), the Toda-Yamamoto (1995) causality test is valid for series that integrated or cointegrated and serves also as an augmented Granger causality test and is formulated as follows:

Let $\mathrm{d}_{\max }=$ maximum order of integration in the VAR system below: The VAR $(\mathrm{c}+\mathrm{dmax})$ shall be estimated to use the modified WALD test for linear restrictions on the coefficients of VAR which follows an asymptotic $\mathrm{X}^{2}$ distribution. Using the Akaike Information Criteria SBC, $\mathrm{C}$ is determined to be ...

To increase the number of lags in the WALD model up to the maximum cointegration level of variables entered in the model is crucially fundamental in opting for the Toda-Yamamoto causality testing procedure. The Toda-Yamamoto approach is an alternative causality testing approach based on the Granger causality equation but augmented with extra lags determined by the potential order of integration of the series causally tested. Employing the seemingly unrelated regression (SURE) framework, we estimated a VAR (4) as follows;

$\left[\begin{array}{l}C B L_{t} \\ L E R_{t} \\ M O S_{t} \\ M P R_{t}\end{array}\right]=\beta_{0}+\beta_{1} \sum_{i=1}^{4}\left[\begin{array}{l}C B L_{t-1} \\ L E R_{t-1} \\ M O S_{t-1} \\ M P R_{t-1}\end{array}\right]+\beta_{2} \sum_{i=0}^{4}\left[\begin{array}{l}L E R_{t-i} \\ C B L_{t-i} \\ C B L_{t-i} \\ C B L_{t-i}\end{array}\right]+\beta_{3} \sum_{i=0}^{4}\left[\begin{array}{l}M O S_{t-i} \\ M O S_{t-i} \\ L E R_{t-i} \\ L E R_{t-i}\end{array}\right]+\beta_{4} \sum_{i=0}^{4}\left[\begin{array}{l}M P R_{t-i} \\ M P R_{t-i} \\ M P R_{t-i} \\ M O S_{t-i}\end{array}\right]+\left[\begin{array}{l}\varepsilon_{t}^{c b l} \\ \varepsilon_{t}^{l e r} \\ \varepsilon_{t}^{m o s} \\ \varepsilon_{t}^{m p r}\end{array}\right] \ldots$

To test that lending rate (LER) does not Granger cause commercial bank loan (CBL), money supply (MOS) and monetary policy rate (MPR), the null hypothesis is stated as:

$\mathrm{H}_{0}: \beta_{\mathrm{ij}}=0$

Versus

$\mathrm{H}_{1}: \beta_{\mathrm{ij}} \neq 0$ where $\beta_{\mathrm{ij}}$ are the coefficients of the variables 


\subsection{Justification for the Model}

The choice of a VAR model to be transformed into a vector error correction mechanism (VECM) is made because it is one of the models that are superior to the ones that are highly vulnerable to simultaneity bias. It offers an easy solution in explaining, predicting and forecasting the values of a set of economic variables at any point in time. It has the ability to test for weak exogeneity and parameter restrictions. It also assumes there is no priory direction of causality among variables. It is a theoretical and does not require any explicit economic theory to estimate the model (Gujarati, 2003). A good attribute of the VAR model is that it obviates a decision as to what contemporaneous variables are exogenous with only lagged variables on the right-hand, and all variables are endogenous.

\section{0 empirical results and Discussions}

4.1 Unit Roots Test Result

In this study, the Augmented Dickey Fuller (ADF) unit roots tests was employed to test for the time series properties of model variables. The null hypothesis is that the variable under investigation has a unit root against the alternative that it does not. The decision rule is to reject the null hypothesis if the ADF statistic value exceeds the critical value at a chosen level of significance (in absolute term). These results are presented in table I below.

Table 1: Unit Roots Test Result

\begin{tabular}{|l|l|ll|l|ll|}
\hline Variable & ADF statistics & \multicolumn{2}{l|}{ ADF statistics } \\
\hline & Level & \multicolumn{2}{l}{ Critical values } & $\mathbf{1}^{\text {st }}$ difference & \multicolumn{2}{l|}{ Critical values } \\
\hline CBL & -0.487356 & $1 \%$ & -3.4708 & -14.45447 & $1 \%$ & -3.4710 \\
& & $5 \%$ & -2.8789 & & $5 \%$ & -2.8790 \\
& & $10 \%$ & -2.5759 & & $10 \%$ & -2.5760 \\
\hline LER & -1.507511 & $1 \%$ & -3.4708 & -13.72950 & $1 \%$ & -3.4710 \\
& & $5 \%$ & -2.8789 & & $5 \%$ & -2.8790 \\
& & $10 \%$ & -2.5759 & & $10 \%$ & -2.5760 \\
\hline MOS & -1.735770 & $1 \%$ & -3.4708 & -15.40390 & $1 \%$ & -3.4710 \\
& & $5 \%$ & -2.8789 & & $5 \%$ & -2.8790 \\
& & $10 \%$ & -2.5759 & -13.51887 & $10 \%$ & -2.5760 \\
\hline MPR & -2.861124 & $1 \%$ & -3.4708 & & $1 \%$ & -3.4710 \\
& & $5 \%$ & -2.8789 & & $5 \%$ & -2.8790 \\
& & $10 \%$ & -2.5759 & & $10 \%$ & -2.5760 \\
\hline
\end{tabular}

The results of table 1 above show that all the variables are non-stationary in level form since their ADF values are less than the critical values at $1 \%$ and $5 \%$ the null hypothesis of a unit root was accepted for all the variables but was rejected in $1^{\text {st }}$ difference. Thus, we conclude that the variables under investigation are integrated of order one. ( i.e. I(1)). Since the variable are integrated of the same order. We therefore, examine their co-integrating relationship using Johansen co-integration procedure.

\subsection{Co-integration Test Result}

A necessary but not sufficient condition for co-integrating test is that each of the variables be integrated of the same order. The Johansen co-integration test uses two statistics test namely: the trace test and the likelihood eigenvalue test. The first row in each of the table test the hypotheses of no co-integrating relation, the second row test the hypothesis of one co-integrating relation and so on, against the alternative of full rank of co-integration. The results are presented in table 2 below.

Table 2: Co-integrating Test Result between the Variables: CBL, LER, MOS and MPR

\begin{tabular}{|l|l|l|l|l|}
\hline Eigen value & Likelihood Ratio & $5 \%$ critical value & $1 \%$ critical value & $\begin{array}{l}\text { Hypothesized No of } \\
\text { CE(s) }\end{array}$ \\
\hline 0.402940 & 56.09390 & 47.21 & 54.46 & None* \\
\hline 0.152230 & 16.89780 & 29.68 & 35,65 & At most 1 \\
\hline 0.054462 & 4.346720 & 15.41 & 20.04 & At most 2 \\
\hline 0.001192 & 1.090663 & 3.76 & 6.65 & At most 3 \\
\hline & & & & \\
\hline
\end{tabular}

*(**) denotes rejection of the hypothesis at $5 \%(1 \%)$ significance level.

L.R. test indicates 1 co-integrating equation(s) at $5 \%$ level of significance

4.2.1 Interpretation of co-integrating results

From table 2 above, the likelihood statistics indicates the presence of one co-integrating equation at 5\% significance level which implies that commercial bank loans (CBL) and lending rate (LER) variables are cointegrated. This shows that there is a long-run relationship between commercial bank loans and lending rate in Nigeria. This further implies causality in at least one direction. 
Table 3: Toda-Yamamoto Causality (modified WALD) Test Results

\begin{tabular}{|l|l|l|l|}
\hline Null hypothesis & Chi-Square $\left(\mathrm{X}^{2}\right)$ & P- value & Conclusion \\
\hline LER does not granger cause CBL & 4.5628 & 0.00004 & Reject Ho \\
\hline CBL does not granger cause LER & 0.7762 & 0.25740 & Do not reject Ho \\
\hline MOS does not granger cause CBL & 1.45145 & 0.14134 & Do not reject Ho \\
\hline CBL does not granger cause MOS & 2.63451 & 0.68951 & Do not reject Ho \\
\hline MPR does not granger cause LER & 6.7834 & 0.00013 & Reject Ho \\
\hline LER does not granger cause MPR & 0.9272 & 0.57840 & Do not reject Ho \\
\hline
\end{tabular}

\subsection{Interpretation of Toda-Yamamoto Causality Test Result}

From table 3 above, the Toda-Yamamoto causality test revealed that lending rate (LER) causes commercial banks loans (CBL) without a feedback. Also monetary policy rate (MPR) causes lending rate (LER) without a feedback while there is no direction of causality between money supply (MOS) and commercial banks loans (CBL). This indicates a strong unidirectional causality running from lending rate (LER) to commercial banks loans (CBL) as well as one way direction from monetary policy rate (MPR) to lending rate (LER) in Nigeria. The conclusion was arrived based on the fact that their Chi-square statistics were statistically significant at $5 \%$ as indicated by their pvalues. This result supports the theoretical view that lending rate which is the cost of borrowing influences the demand for loanable funds in Nigeria. It equally supports the view that monetary policy rate (which is the charges on loans to the commercial banks from Central Bank of Nigeria) have direct influence on lending rate in Nigeria.

\subsection{Conclusion and policy recommendations}

The main findings are itemized below as follows: (a) The ADF results show that the series are non stationary in their level form and are integrated of order one. (2) Johansen co-integration test result shows evidence of cointegration implying a long run relationship between lending rate and banks loan in Nigeria. (3) The TodaYamamoto causality test indicates a strong unidirectional causality running from lending rate to banks loan and from monetary policy rate to lending rate in Nigeria.

Based on the research findings, the following recommendations were made to arrest the enumerated problems. Since there is a unidirectional causality running from lending rate to banks loan and from monetary policy rate to lending rate, appropriate monetary policy should be pursued. To achieve this, monetary authority (CBN) should maintain a relatively moderate and stable monetary policy rate which will in turn will influence a moderate lending rate that will enable investors (both domestic and foreign) have access to more loans and hence increase in investment, productivity and employment in the country.

\section{References}

Adegbola, E.A.; Fadipe, T.G. \& Olajide, A.T. (2015). Monetary theory and policy. Department of Banking and Finance. Lagos: National Open University of Nigeria.

Afolabi , Adeyemi , Salawudeen , and Fagbemi, (2018), Monetary Policy and Bank Credit in Nigeria: A TodaYamamoto Approach Acta Universitatis Danubius Vol 14, no 5, 2018.

Akinlo, A. E., and Oni, I. O. (2015). Determinants of bank credit growth in Nigeria 1980-2010. European Journal of sustainable development, 4(1), 23.

Agbonkhese, A.O. \&Asekome, M.O. (2013). The impact of monetary policy on bank credit creation in Nigeria. International Journal of Business and Social Science, 4(15), pp. 160- 165.

Ajayi, F. \&Atanda, A. (2012). Monetary policy and bank performance in Nigeria: A two-step cointegration approach. African Journal of Scientific Research, 9(1), pp. 34-47.

Al-Kilani, Q. A., and Kaddumi, T. A. (2015). Cyclicality of Lending Behavior by Banking Sector for the Period (2000-2013): Evidence from Jordan. International Journal of Economics and Finance, 7(4), 57.

Amidu, M. (2006). The link between monetary policy and banks' lending behavior: The Ghanaian case. Journal of Banks and Banking System, 1(4), pp. 38-48.

Andreas, W. (2001). The reaction of bank lending to monetary policy measures in Germany. Working paper no. 96.

Ayieyo, J. O. (2016). Determinants of Lending Behavior in Selected Commercial Banks in Kenya. International Journal Of Economics, Commerce And Management, 2(9).

Ayub, G. \& Seyed, A.M. (2016).The relationship between monetary policy and bank lending behavior andthe influence of bank specific features on this relationship in the banks listedon the Tehran Stock Exchange. International Journal of Advanced Biotechnology and Research (IJBR) Vol. 7(2).

Benchimol, J., Fourçans, A., (2013). Money and risk in a DSGE framework: a Bayesian application to the Eurozone. Journal of Macroeconomics 34 (1), 95-111.

Buiter, Willem H. (2009), 'The unfortunate uselessness of most "state of the art" academic monetary economics', Vox EU, 6 March. http://www.voxeu.org/article/macroeconomics- crisis-irrelevance. 
Chernykh. L., Theodossiou., A. (2011). Determinants of bank long term lending behavior: Evidence from Russia. Multinational Finance Journal, 15(1), 193-2.

Jegede, C.A. (2014). Impacts of monetary policy on the commercial banks'lending in Nigeria. Review of Public Administration and Management, 3(5), pp. 134 - 146.

Gichuki, J., Oduor, J. and Kosimbei, G. (2012). " The choice of optimal monetary policy instrument for Kenya." International Journal of economics and management Sciences Vol. 1, No. 9, pp 01-23. Management journals.org

Hameed, I. \& Ume, A. (2011). Impact of monetary policy on gross domestic product (GDP).

Published in: Interdisciplinary Journal of Contemporary Research in Business , Vol. 3, No. 1 (May 2011): pp. $1348-1361$.

Hanh, P. T. H. (2014). Determinants of bank lending. LEMNA, Institue of Economics and Management University of Nante. Retrieved from https://hal.inria.fr

Ladime, J., Sarpong-Kumankomah, E., and Osei, K. A. (2013). Determinants of bank lending behavior in Ghana. Journal of Economics and Sustainable Development, 4(17), 42-47.

Malede, M. (2014). Determinants of Commercial Banks Lending: Evidence from Ethiopian Commercial Banks. European Journal of Business and Management, 6(20), 109-117.

Okpara G. C (2009) Paper presentation on the topic: "A Synthesis of the critical Factors

Affecting performance of the Nigerian Banking System" published in European Journal of Economics ISSN 1450 - 2887 Issue 17 (2009)

Otalu, Aladesanmi \& Mary (2014). Monetary policy and commercial banks performance in Nigeria: an assessment of credit creation role. The International Journal of Business and Management, 2(7), pp. 45-51.

Rabab'ah, M. (2015). Factors Affecting the Bank Credit: An Empirical Study on the Jordanian Commercial Banks. International Journal of Economics and Finance, 7(5), 166-178.

Roussakis, E.N (1977). Managing commercial bank fund. New York: Praeger Publisher

Sepehri, Ardeshir, and Saeed Moshiri (2004). Inflation-Growth Profiles Across Countries: Evidence from Developing and Developed Countries. International Review of Applied Economics 18, pp. 191-207.

Toda, H.Y. \& Yamamoto (1995) Statistical inference in Vector Autoregressions with possibly integrated processes. Journal of Econometrics, 66, 225-250.

Tsenkwo, B.J. \&Longdu'ut, D.T. (2013). The Relationship between Monetary Policy Rate (MPR) and Banking Rates: Evidence from Regression and Multivariate Causality AnalysisAn International Journal of Arts and Humanities, 2(3). 